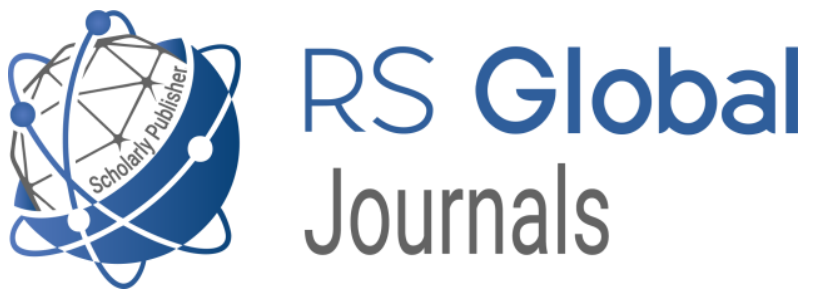

Scholarly Publisher

RS Global Sp. z O.O.

ISNI: 0000000484952390

Dolna 17, Warsaw, Poland 00-773

Tel: +48226022703

Email: editorial_office@rsglobal.pl

JOURNAL International Journal of Innovative Technologies in Social Science

p-ISSN

$2544-9338$

e-ISSN

2544-9435

PUBLISHER

RS Global Sp. z O.O., Poland

ARTICLE TITLE

MICHEL MOUSKHELY - ON THE ESTABLISHMENT OF THE COUNCIL OF EUROPE AND VISA-FREE TRAVEL TO EUROPE

$\operatorname{AUTHOR}(\mathbf{S})$

Edisher Japharidze, Vazha Shubitidze

Edisher Japharidze, Vazha Shubitidze. (2021) Michel Mouskhely - on the Establishment of the Council of Europe and Visa-Free

ARTICLE INFO Travel to Europe. International Journal of Innovative Technologies in Social Science. 1(29). doi: $10.31435 /$ rsglobal_ijitss/30032021/7455

DOI https://doi.org/10.31435/rsglobal_ijitss/30032021/7455

RECEIVED

24 December 2020

ACCEPTED

15 February 2021

PUBLISHED

20 February 2021

LICENSE

This work is licensed under a Creative Commons Attribution

4.0 International License.

(C) The author(s) 2021. This publication is an open access article. 


\title{
MICHEL MOUSKHELY - ON THE ESTABLISHMENT OF THE COUNCIL OF EUROPE AND VISA-FREE TRAVEL TO EUROPE
}

\author{
Edisher Japharidze, \\ Georgian Technical University, Tbilisi, Georgia \\ Vazha Shubitidze, \\ Georgian Technical University, Tbilisi, Georgia
}

DOI: https://doi.org/10.31435/rsglobal_ijitss/30032021/7455

\section{ARTICLE INFO}

Received 24 December 2020

Accepted 15 February 2021

Published 20 February 2021

\section{KEYWORDS}

European Integration, Council of Europe, Visa-liberalization in Georgia, Georgian

Emigrants Micheil

Muskhelishvili and Aleksander Nikuradse.

\begin{abstract}
The European integration processes is not losing its topicality to this day. It still remains as the important political challenge of the 21 st century in the geopolitical area of the modern world. In these processes Georgia is actively participating today too, as it is known an agreement of the association between Georgia and the European Union was signed in summer 2014. This fact was a landmark of the greatest historical importance for Georgian people. It means returning of the Georgian people to its initial homelandEurope, which always struggled and strived for it. It must be noted that we are not entering the Europe with empty hands but are widely credited with the propaganda of European qualities and bringing them to Georgia. It is still not widely known to the general public that at the starting point of uniting the European Union (European Confederation) were standing famous Georgian scientists and public figures. M. Muskhelishvili and A. Nikuradze. While Robert Schuman and Jean Monnet talked about the idea of uniting Europe, M. Muskhelishvili and A. Nikuradze were publishing articles on the same subject in the leading newspapers and magazines and actively participated in the processes of creating the European Union.
\end{abstract}

Citation: Edisher Japharidze, Vazha Shubitidze. (2021) Michel Mouskhely - on the Establishment of the Council of Europe and Visa-Free Travel to Europe. International Journal of Innovative Technologies in Social Science. 1(29). doi: 10.31435/rsglobal_ijitss/30032021/7455

Copyright: (C) 2021 Edisher Japharidze, Vazha Shubitidze. This is an open-access article distributed under the terms of the Creative Commons Attribution License (CC BY). The use, distribution or reproduction in other forums is permitted, provided the original author(s) or licensor are credited and that the original publication in this journal is cited, in accordance with accepted academic practice. No use, distribution or reproduction is permitted which does not comply with these terms.

Federalism gives us great hope. thanks to him Europe will become the land of men, Western civilization - is a hearth of new humanism. Michel Mouskhely

Michel Mouskhely about European integration process.

Integration with the European structures and practical implementation of western orientation became the main starting point and obtained a special actuality in modern Georgia. It's natural that achieving the set goal is not a simple matter and it's important to make the measurable steps, considering the political or social-economical processes, as well complete knowledge of historical experience and using them on the way of future development of Georgia. On this background we 
think it's important to evaluate the activity of such persons and introduce to the wide audience, such are Mikheil Muskhelishvili ${ }^{1}$ and Aleksandre Nikuradze ${ }^{2}$.

Goal of evaluating and analyzing of the material, provided in this work, is not only discussion of life and activity of the above-mentioned persons, but to expose the historical experience of GeorgianEuropean relation and what is the main, to maintain the existing offset during the process of strengthening the future relations and to outline the new ways. In a word, thorough processing of archive and documentary materials and detailed analysis gave me the possibility to make the following conclusions:

The structure of this paper reflects the appropriates of Georgian emigrants history of Micheil Muskhelishvili and Aleksandre Nikuradze's initiatives in European integration process, which they played a major part of European values and attitudes establishing process in Europe.

What does Europe really mean, what does Europe represent, what nations and nations do Europe mean? Paul Valerie, the great French poet and thinker, a true European, expressed a very interesting opinion on this matter: "All races, all lands which were sequentially romanticized, Christianized, are subject to the discipline of the Greek discipline and are absolutely European" (Mikhail Muskhelishvili, "Georgia and Europe"). According to this formula by Paul Valerie, Georgia is as European as Poland, Hungary or any of the others. If we do not take into account the remains of the oldest human in Europe (1.8 million years ago) found in the territory of Dmanisi, twice the age of the ancient analogues found in Spain and Italy (Atapuero and Ceprano, 800,000 years old), then Georgians' relations with European civilization, Medea, the "Golden Fleece" and the Greek expedition to Jason Ebony in Colchis) counts for more than 30 centuries. Yes, Georgia is a European country. According to prominent archaeologists, this is where Europe begins. According to the well-known scientist Varaniak, the first great wave of Iberian-Caucasian tribal emigration to Europe was actually initiated from Georgia, which created the first great civilization. This civilization is shared by Indo-Europeans who came to Europe several thousand years ago. Later, close relations were established between Georgia and Greece (the establishment of trade emphorions by the Greeks on the Georgian Black Sea coasts and trade-cultural relations).

Pompeius brought Rome to Georgia (65 BC) and already Christianity invaded Georgia in the first century of the census, which covered the whole country at the turn of the third and fourth centuries. Thus, at the dawn of Western civilization, Georgia participated in it, and its gaze was always directed towards the West (Peter Iber, George Mtatsminda, Kings: David IV the Builder, Tamar, George IV Lasha, George V the Magnificent, Simon King, Teimuraz I, Vakhtang VI, Sulkhan), Erekle II, etc. Until Georgia was joined by Russia in deception and deceit.

According to prominent Georgian immigrant scientist Professor Mikheil Muskhelishvili, "There was a time when Georgians learned that they belonged to Europe. Europe is now (meaning the beginning of the 1950s) making this conclusion.

It is also necessary for Georgians to prove their existence in Europe and for Georgia to be accepted in the family of Western nations ${ }^{3}$.

Thus, Europe and Europe are determined not by geography, race, language, or morality, but by the undeniable qualities of his soul, the soul which is the successor of the three influences defined by Paul Valerie.

According to him, Russia has twice turned its back on Europe (after Peter the First and since 1917), and Georgia has always been on its way to Europe ... Georgia, with its historical and social core, is a piece of Europe, Western culture, and to stop it on the mid-way through foreign power strikes and for him to come up with a non-European relationship would be the death of the people, the

\footnotetext{
${ }^{1}$ Micheil Muskhelishvili (Michel Mouskhely) was born in Tbilisi (1903-1964). He studied at Gottingen, Munich, Lyons and Paris University. In 1948, he became a professor of international Law and Economic Sciences at university of Strasbourg. He wrote the first European federal constitution with Gaston Stefan which was submitted to the international coordinating committee of the Movements for European Unity, but had direct effect on the latter's work. Today European Law provided for Michels's work federalism Constitution.

${ }^{2}$ Alexsander Nikuradse (By his pseudonym Al. Sanders) was born in Samtredia (1900-1981). He studied in Germany and became Munich, Berlin, Gotingen University Professor and he founded Center in Munich (Institute für Kontinental Europaeische Forschung). He conceived an ambitious project of the German protectorate over the project Caucasian Confederation in which the Georgian were to play the leading role. He worked on European integration and Europology issues. He was well knew physicist too which investigated dielectric materials and the theories of electrons and ions too.

${ }^{3}$ Mikheil Muskhelishvili, Europa and Georgia, Georgia's Relations with European and American Countries, TB; 1995, Volume II
} 
extinction of the nation. Russia does not expect such extinction as it stands on its historical basis; Asianity, after all, should be turn into Europeanism. It is a natural procession, but it is a complete mess of the natural procession of the European nation - Georgia - by force turn into Asian State.

It is a deadly leap ... Tying our future with Russia's future means our complete destruction not only politically and nationally but also physically ... Democracy cannot fall from the tree of Bolshevism. This is a distant stage. That is why we want Georgia to break away from these Russian asperities in a timely manner, restore its sovereignty and move forward in its own way... the Georgian nation must eventually join the European family"1.

The government of independent Georgia occupied by Soviet Russia under the leadership of Noah Jordania in 1921 emigrated not to Iran-Turkey, where our authorities used to go, but to Europe. While still in government, they laid the practical groundwork for Georgia's European orientation and modern European socio-democratic ideas and direction in Europe since 1918. Two prominent Georgian immigrant researchers, professors Mikheil Muskhelishvili [1903-1964] and Alexander Nikuradze (19011981) are among the prominent European scholars and politicians known for developing and implementing the idea of modern European integration. Georgia started returning to Europe when we received Christianity and became part of the Hellenistic world, a participant of Roman and Greek civilization. Georgia has never stopped moving towards Europe. It was following the course of the civilization of European countries and was ahead of them in many respects. One of these exceptions is United Europe's Apologist, President of the Congress of European Peoples, Member of the Central Committee of the "Federal European Movement", Vice-President of the Bureau of the International Center for the Formation of Europe, Founder and Secretary General of the European University Association, well-known European politician Mikheil Muskhelishvili (known in Europe as Michelle Mouskhely) and Professor of the University of Berlin, Alexander Nikuradze, founder of the first Continental European Research Institute in Europe. The first worked in France and the second in Germany. They actively participated in the implementation of the idea of united Europe and creation of Federation. According to Muskhelishvili, European federalism - this is not only a vital necessity for the European nations, but also a guarantee of peace and the guarantee of common prosperity, freedom and dignity in Europe, he wrote in the paper "The Structure of European Federalism".

The first Idealist of the European Community and the European Union concept was M. Muskhelishvili, a leading professor of the Department of International Public Law, Political and Economic Sciences at the University of Strasbourg, who at a time when Jean Monnet and Robert Schumann were talking about the idea of European unification, already put forward significant initiatives both for the idea of institutionalizing Europe and creating the legal basis for Europeanization. However, before moving on to legal initiatives, it is very important to focus on the three most important aspects of his work. They relate to the establishment of important institutions in Europe, which later have begun to further the European institutional development and Europeanization process. The first - it was the creation of a research center that covered all of Europe. M. Muskhelishvili in 1948-1949 founded the Scientific Research Center of the USSR and Eastern Europe (the so-called Socialist). He has been in charge of this center for 18 years. It was later called the Mouskhely Center (It's still called today). The center was one of the most important hearth of political science and international law in the field of sociology in France, where the idea of European integration and the removal of borders was being worked out. He was one of the first political figures in the world to propose and defend the idea of taking over the European Union and European borders ${ }^{2}$.

Secondly, he was involved in the creation and establishment of the Council of Europe (1949) from the beginning. This Council laid the groundwork for the guarantee of human rights in Europe. Since 1952, M. Muskhelishvili has been in possession of ,the mandate of the Council of Europe's Advisory Assembly", and has been actively involved in the work of the Council of Europe.

The third direction of the politician's work is as follows: he formed „the Georgian-European Movement" - the first apolitical union focused on democratic values and liberal values. On August 10, 1953, the first "Georgian-European Movement" was officially founded in Strasbourg, inspired and initiated by Mikheil Muskhelishvili. The "Georgian-European Movement" was based charter, which was drawn up and approved by the Constituent Assembly of Munich, gathered on April 7, 1953 in

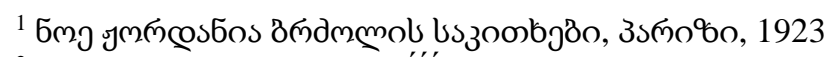

2 The Newspaper Figaro, 2. ÍIÍ. 1965
} 
St. Petersburg: 1) Spreading the idea among the Georgians of the European Union and the need for Georgia to join this Union as a sovereign and democratic State. 2) To inform foreigners that Georgia has always been a part of Europe spiritually and culturally and wants to become a member of it. To achieve these goals, he contacts with the Caucasian Neighbors and other European nations. The Charter of the Movement states that ,the Georgian-European Movement" was not belonging of any party or group. Any Georgian, regardless of religious and political beliefs, who recognized Georgia's sovereignty and shared the idea of European integrity could participate in it ${ }^{1}$.

When it goes to the legal side of Europeanization process, the following initiatives are particularly important from M. Muskhelishvili's works:

In 1948, M. Muskhelishvili, together with French constitutionalist Gaston Stefan, create a draft project of the European Federal Constitution, "M. Muskhelishvili, Gaston Stefani, Draft of a European Federal Constitution 1948", detailing the principles of political and social democracy. It is based on peace and social justice in the context of the unity of the federation and the diversity of the federal states. It is noteworthy that modern European law is richly nourished by the principles of law initiated by Muskhelishvili (most notably his fundamental papers on fundamental human rights and freedoms).

On August 6, 1950, the day before the opening of the European Conference in Strasbourg, more than 300 students from 8 European states, led by passionate European Union initiator M. Muslkhelishvili and three other professors, dismantled the French-German border infrastructure and raised the united Europe's flag, "We just light a small fire, big bonfires now need to be lit up in Strasbourg so that European hearts can be lighten," said M. Muskhelishvili².

In September, 1955, At the World Congress which took place in city of Trieste, attended by 120 participants from 18 countries, the keynote speaker $\mathrm{M}$. Muskhelishvili. addressed the representatives of Civilized World's countries: Now the time has come for the intellectual and cultural unification of Europeans, which, in the first place, meant the modernization of the unified European education system, the project approaching the present-day Bologna process, the prospects for European intellectual mass mobility and convergence, Europe Harmonization of educational programs. M. Muskhelishvili was at the time initiating the development of unified teaching methods in the higher education institutions of European countries, the mobility of professors and students of European higher education institutions and the development of good relations ${ }^{3}$

M. Muskhelishvili was initiating the creation of a common European market in Brussels and in the international tribunes of Europe. On April 23-27, 1958, at the Pavilion of the World Exhibition C.E.C.A in Brussels, the next meeting of the European Professors' Association was held. There were two issues on the agenda: Europe's common market and Europe's common institutions. The reports concerned the legal nature of European economic integrity and its general aspect, its psychological side. M. Muskhelishvili gave an extensive report here on the creation of the European common market, its integration and its legal aspects. He believed that the European market should be united after the European Union, which would facilitate trade between the countries and create a single market system on the European continent. The creation of a common market system would promote the consolidation of European countries and strengthening of this process. ${ }^{4}$

In addition to Mikheil Muskhelishvili's initiatives, the contribution of Alexander Nikuradze, a professor at the University of Berlin, to the development and development of interdisciplinary Europe as an interdisciplinary field is also interesting. On the initiative of Alexander Nikuradze in September 1952 in France, a congress of European scientists was held near the city Compienne in the Labrévier Palace. The subject was discussed, in particular, among other proposals, the Congress adopted in order to introduce the notion of the term "European Studies", which originally meant to bring together European scientific disciplines and to form one field of study. Also, the initiative was to create and develop a separate branch of the "Volkswirtschaft" economy, which would deal only with economical study issues. Since then, the use of such terms as "European Studies" and "the Volkswirtschaft" economics in science and their placement in European higher education institutions is connected with the name of Professor Alexander Nikuradze ${ }^{5}$.

\footnotetext{
${ }^{1}$ The Journal "Bedi Kartlisa" \# 15, September 1953.

${ }^{2}$ Spiegel der Sudpfalz, Thema am Samstag, revolution fur Europain St. Germanshof, Samstag, 5 August, 2006

${ }^{3}$ The Journal "Bedi Kartlisa" \# 21-22, April 1956

4 The Journal "Bedi Kartlisa" \# 28-29, Congress of the European Professors' Association, June 1958.

5 The Journal "Bedi Kartlisa" No. 10, by Professor Al. Nikuradze in Paris, 1951
} 
Al. Nikuradze also worked on a project of the Caucasian Confederation, which envisaged Georgia becoming a leader in the Caucasus region. All of this had to happen with the German protectorate and on the basis of the economy of the Transcaucasus. He believed that the way to maintain Georgia's independence and sovereignty was to run its economy. Even then A. Nikuradze and prominent German economists, including director of the Eastern Economic Institute, M. Akhmeteli, were convinced that Georgia would become the most economically important bridge in the future to transit Europe and Asia. The geographical and geostrategic location of Georgia was considered as the main factor for this. He has been extensively discussing these issues and has published important German-language papers on Georgian-European relations and parallels, in particular: "The Caucasus", "On the Issue of Georgian Architecture in the Medieval European East", "Patri Mikhail Tarkhnishvili (due to death)", "Scandinavians and Georgians on the Pont-Baltic Coast", "Dr. Otto Gunter von Wesendok as Kartvelologist", "Historiographical Views on Albania", "Trying to explain the parallels between Western Europe's Roman architecture and Georgian architecture", "Western Europe and the Caucasus as parallels", "Sumerian primates" and others ${ }^{1}$.

In addition, A. Nikuradze has published more than 35 high-level scientific papers in the field of physics and mathematics. Notable among these are "Liquid Dielectrics" (Al. Nikurade, Das Flüssige Dialektrikum, Berlin, 1934), which Russian translation was published in Moscow-Leningrad. It states that such work did not exist in Russian. It was a rare precedent when the fundamental work of a Georgian physicist emigrating to the Soviet Union was published. This work was used throughout the whole Soviet Union. It is still used as a textbook in various higher education institutions today.

Realization of Mikheil Muskhelishvili's idea in Georgia, 25 years after its independence was implemented in the form of "visa liberalization". On February 2, 2017 Georgia received the right to visa-free travel (visa liberalization) in the Schengen Member States. This is a result of the successful reforms implemented by the democratic government of Georgia in the country; and we hope this will be another step forward for Georgia's EU integration.

Therefore, the political and legal initiatives presented here testify that one of the first apologists for the idea of a European Union was M. Muskhelishvili.

Thus, adopting today's visa liberalization is one way in which M. Muskhelishil's four key concepts are implemented. This concept originally meant: the unification of European countries (European Union, Confederation), the creation of a common European market, the demarcation of borders between European countries, the creation and harmonization of the European single education system. Georgia has been actively involved in the last two concepts, and the rest remains the country's main challenge. We hope that by taking successful measures, Georgia will soon join the European common market and at the same time eventually return to the European family where it will take its own place.

Based on the above, we can conclude: Georgia's European orientation has no alternative, that the Georgian people will inevitably eventually return to their original homeland - Europe, with its blood and flesh, and to which Georgia always has been strived by its culture, religion and political system ... At the same time, it must be said that there is a significant Georgian contribution to the development of European integration and "Europeanology", which we can be justly proud of.

Conclusions. Georgia has always been the centuries long to aspire to Europe. Today Georgia is pursuing thoroughly the path of western orientation. From the beginning of European History, Georgia participated in the development of Humanity of spiritual, cultural, political and economic formations in forming, which it constituted the essence of European life. We became Europeans then, when we got Christianity and to became part of Hellenistic world and share of Roman and Greek Civilization. Georgia is giver of share in the European creative works. It is very important to designate Georgian emigrant professor merits in the development and forming of European Union. M. Muskhelishvili was the first Georgian European who preached about the idea of Creating European Union in his way and erasing frontiers among European countries. He formed the European Center of scientific research and study in Strasburg named "Mouskhel" center (where it is operating with the name) which researched European integration issues. After the War he raised the idea of uniting Europe and its federation and protected it. To his opinion, European federalism is not only surviving necessity for European people but also a guarantee of peace and for general flourishing in Europe, freedom and integrity of human race..., he wrote in his work "The structure of Europe's federalism"2.

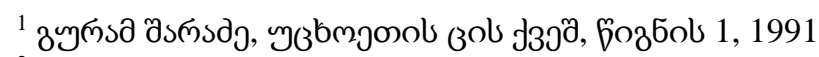

${ }^{2}$ Spiegel der Sudpfalz, Thema am Samstag, revolution fur Europain St. Germanshof, Samstag, 5 August, 2006 
Till Jean Monnet became founder of EU, for this time M. Muskhelishvili had publish many publications about European confederation and they found many scientific Center of EU for EU. While Robert Schuman and Jean Monnet talked about the idea of uniting Europe, M. Muskhelishvili were publishing articles on the same subject in the leading newspapers and magazines and actively participated in the processes of creating the European Union.

In Strasburg in August of 1950, Michel Mouskheli with him students and supporter of European Union was demolished France-German frontier infrastructure and he hoisted common European flag. He said that we had light a fire, the big one fire should be kindling in Strasburg now that European Heart will be relight.

M. Muskhelishvili talked also about European common market creating and European common educational system creating and harmonization which it meant bologna process today. We hardly can say that bologna process ideology is on the base of M. Muskhelishvili's law conceptions. The aim is getting close to European countries educational system and harmonization, and creating of European common educational system for high education

Georgia got EU visa liberalization in 2 February of 2017 (VLAP-Visa Liberalisation Action Plan). It was result of success reforms which it was realized by Georgian Democratic Government and we hope that it will be the beginning of integration process of Georgia to European Union.

At the present time Visa liberalization represents Michel Mouskheli's four main conception for the creating of European Union, which he fought for it. The conception meant at that time, European Countries Union (EU, Confederation), Creating of European common market, Demolish border between European countries and creating of European common educational system and harmonization. Georgia already participated in last two conception and another conceptions are also main provoke for Georgia too. We hope that Georgia will connect with success follow up reforms to European common market and finally Georgia will return own in European family.

Also, thus, it can be said that at the initial point of European Integration were standing the First in the world famous Georgian emigrant scientists M. Muskhelishvili, who are widely credited with forming and developing the European Union. 